\title{
Impact of Infrastructure Availability to the Level of Slum Area in Banyumanik District
}

\author{
Khristiana Dwi Astuti ${ }^{1, \text { a) }}$, Pangi ${ }^{1, b)}$, Bayu Ika Mahendra ${ }^{2, c)}$ \\ ${ }^{1}$ Vocational School, Diponegoro University \\ ${ }^{2}$ Master or Urban and Regional Planning, Diponegoro University. \\ a) Correspondence author: khristiana.dwiastuti@live.undip.ac.id \\ b) pangi@pwk.undip.ac.id \\ c)bayu.im@gmail.com
}

\begin{abstract}
Slum especially in big cities such as Semarang City occurred not only in the inner city but also spread to the suburbs of Semarang City, one of them in Banyumanik District. Based on the Decree of Mayor of Semarang no. 050/801/2014 about Determination of Slum Location at Semarang City, there are 6 (six) urban villages in Banyumanik District which have slum areas. Determination of the slum area is based on the Semarang City Slum Inventory Study from 2010 to 2014. As a consequence, it is known that the main problem causing the development of slum settlement is related to the availability of environmental infrastructures : road network, sanitation, clean water, and drainage. This research was conducted to determine the slum level in the slum areas located in Banyumanik district based on the availability of environmental infrastructure. The analysis included descriptive analysis to explain the characteristics of slum settlements and the availability of existing environmental infrastructure, and scoring analysis to determine the impact of the availability of this infrastructure on the slum level. Based on the results of the analysis, shows that the slum settlements in RT 01 / RW IV of Jabungan have the highest slum level in Banyumanik district.
\end{abstract}

Keywords : infrastructure, availability, slum area

\section{INTRODUCTION}

Development that occurs in a region or city can be identified from various conditions, both physically and non-physically related to the social condition of the community. One form of development which can be seen physically is settlements expansion as an implication of urban population growth, changes in socioeconomic conditions, and interactions contained in it [1].

The population growth phenomenon is not balanced with the provision of the infrastructure of the city. Therefore, the development that occurs actually results in a decrease in environmental quality, potentially create slum settlements. Most of the time, slums grow naturally and cannot be avoided. Slum with various conditions not only revolve around the inner city but also to the periphery.

The slum develops due to the demand of occupancy for people who are coming from other areas [2]. The migrant initially aims to find better jobs and livelihoods in the city. However, high competition and no skills required by the jobs causes them work in the informal sector. The main work of the informal sector affects the purchasing power to have a comfortable house for both location and condition of the building. As a result, there emerged slums with a variety of poor conditions, including limited physical structures, quality of buildings that did not have health requirements, limited environmental infrastructure, and so on [3].

Semarang City as the capital of Central Java Province is one of the big cities in Indonesia which is in the process of growth and development. Currently, Semarang City has developed into a large city that has a variety of functions, as a regional administrative center, and is devoted to trade and services. This is in line with the vision of RPJMD (medium-term development plan) Semarang 2016-2021 "Semarang City of Great Trade and Services Toward Increasingly Prosperous People" [4]. This is certainly a positive implication for Semarang City 
itself. On the other hand, it presents a challenge because the development will bring more diverse activities that encourage the fulfillment of supporting infrastructure, one of which is the need for housing.

The housing needs are met through the planned and unplanned housing, under various conditions. When a house that is occupied is no longer following the prerequisite of a healthy house, it will become a slum neighborhood. Slum areas have a limited level of infrastructure and basic facilities environment services, especially the limitations to obtain services clean water facilities, drainage and sanitation [5] [6].

Under the Decree of Mayor of Semarang No. 050/801/2014 about Determination of Slum Location at Semarang City, it is determined that Semarang has 415,83 Ha slum that is spread in 62 (sixty-two) sub-district. Among these slum locations, 6 (six) sub-district are located in Banyumanik district, i.e.: Ngesrep, Padangsari, Jabungan, Tinjomoyo, Srondol Kulon, and Gedawang .

That determination is influenced by the environmental infrastructure availability in settlement area, which includes: road network, clean water, sanitation, drainage, and garbage [7].

\section{INFRASTRUCTURE AVAILABILITY AT SLUM AREA}

Referring to the Slum Settlement Management Program of Semarang City, the main problem causing slum is related to the availability of road network, drainage, clean water and sanitation [8]. According to Law No.1/2011 about Housing and Residential Areas, the infrastructure is the basic physical completeness of a residential environment with specific standards to stay: healthy, safe and comfortable. The regulation, Guidelines of the Slum Identification at the Metropolitan Buffer Area [7] explained that a slum settlement area must have road network, drainage network, clean water network, wastewater network and solid waste network.

The existence of environmental infrastructure has a vital role in supporting the activities of a settlement. In addition, infrastructure as a physical facility becomes a potential factor in determining the success of a region's development [9].

\section{METHODS}

The method used to describe the characteristics of the slum in Banyumanik District is descriptive statistic, which is related to the number and physical condition of the house, and the socio-economic condition of the community. In addition, descriptive analysis is also conducted to determine the characteristics of the availability of environmental infrastructure in the slum area. That condition identified by observing the phenomenon of slums growth that found in large cities, including Semarang. Based on the tendency of slum settlements, there is a decrease in the quality of settlement environment, which is influenced by the limited availability of environmental infrastructure [10].

TABLE 1. Research Variables

\begin{tabular}{|c|c|c|}
\hline \multicolumn{2}{|r|}{ Variable } & Measured Parameter \\
\hline \multirow{3}{*}{ Slums area } & $\begin{array}{c}\text { General } \\
\text { characteristics }\end{array}$ & $\begin{array}{ll}- & \text { The dimension of the house } \\
- & \text { Number of houses } \\
- & \text { Number of household members }\end{array}$ \\
\hline & Physical condition & $\begin{array}{l}\text { - } \begin{array}{l}\text { Building conditions (floor, wall, roof, and } \\
\text { distance between buildings) }\end{array} \\
\end{array}$ \\
\hline & $\begin{array}{l}\text { Socio-economics } \\
\text { condition }\end{array}$ & $\begin{array}{ll}- & \text { Income level } \\
- & \text { Education level } \\
\end{array}$ \\
\hline \multirow{5}{*}{$\begin{array}{l}\text { Settlement } \\
\text { infrastructure }\end{array}$} & Road network & $\begin{array}{ll}- & \text { Road condition } \\
- & \text { Road material } \\
\end{array}$ \\
\hline & drainage & $\begin{array}{ll}- & \text { Network availability } \\
- & \text { drain dimensions } \\
- & \text { drain condition } \\
\end{array}$ \\
\hline & Clean water & $\begin{array}{ll}- & \text { water sources } \\
- & \text { fresh water quality } \\
\end{array}$ \\
\hline & sanitation & $\begin{array}{ll}- & \text { private latrine } \\
- & \text { commmunal latrines } \\
- & \text { management of communal latrines } \\
\end{array}$ \\
\hline & Solid waste & $\begin{array}{ll}- & \text { number of the private trash bin } \\
- & \text { the household waste disposal system } \\
- & \text { number and location of the garbage dump }\end{array}$ \\
\hline
\end{tabular}


Meanwhile, scoring analysis is used to provide an assessment of the availability and service of infrastructure in each sub district that has slum areas in Banyumanik. Through these assessments then the analysis was used to determine the slum level in the study area.

TABLE 2. The Criteria That Used for The Analysis

\begin{tabular}{|c|c|c|c|c|}
\hline No & Variable & Object & Score & Criteria \\
\hline \multirow[t]{3}{*}{1} & \multirow{3}{*}{$\begin{array}{l}\text { Road } \\
\text { condition }\end{array}$} & \multirow[t]{3}{*}{ Neighborhood road } & 50 & Bad condition $>70 \%$ \\
\hline & & & 30 & Medium condition $50 \%-70 \%$. \\
\hline & & & 20 & Good condition $<50 \%$ \\
\hline \multirow[t]{3}{*}{2} & \multirow{3}{*}{$\begin{array}{l}\text { Drainage } \\
\text { condition }\end{array}$} & \multirow[t]{3}{*}{ Drainage network } & 50 & Bad condition $>50 \%$ \\
\hline & & & 30 & Medium condition $25 \%-50 \%$. \\
\hline & & & 20 & Bad condition $<25 \%$ \\
\hline \multirow[t]{3}{*}{3} & \multirow[t]{3}{*}{$\begin{array}{l}\text { Clean water } \\
\text { condition }\end{array}$} & \multirow{3}{*}{$\begin{array}{l}\text { The number of houses } \\
\text { in residential areas that } \\
\text { have obtained water } \\
\text { flow from the water } \\
\text { supply system. }\end{array}$} & 50 & $\begin{array}{l}\text { The area with the level of piped water system } \\
\text { service }<30 \%\end{array}$ \\
\hline & & & 30 & $\begin{array}{l}\text { The area with the level of piped water system } \\
\text { service } 30 \%-60 \%\end{array}$ \\
\hline & & & 20 & $\begin{array}{l}\text { The area with the level of piped water system } \\
\text { service }>60 \%\end{array}$ \\
\hline \multirow[t]{3}{*}{4} & \multirow{3}{*}{$\begin{array}{l}\text { Sanitary } \\
\text { condition }\end{array}$} & \multirow{3}{*}{$\begin{array}{l}\text { Sanitation in the } \\
\text { residential area }\end{array}$} & 50 & Areas with sanitation services $<30 \%$ \\
\hline & & & 30 & Areas with sanitation services $30 \%-60 \%$. \\
\hline & & & 20 & Areas with sanitation services $>60 \%$ \\
\hline \multirow[t]{3}{*}{5} & \multirow[t]{3}{*}{$\begin{array}{l}\text { Garbage } \\
\text { condition }\end{array}$} & \multirow[t]{3}{*}{$\begin{array}{l}\text { Solid waste in the } \\
\text { residential area }\end{array}$} & 50 & $\begin{array}{l}\text { The area with the level of garbage service } \\
<50 \% \text {. }\end{array}$ \\
\hline & & & 30 & $\begin{array}{l}\text { The area with the level of garbage service } 50 \% \text { - } \\
70 \%\end{array}$ \\
\hline & & & 20 & $\begin{array}{l}\text { The area with the level of garbage service } \\
>70 \% \text {. }\end{array}$ \\
\hline
\end{tabular}

\section{SLUM CHARACTERISTIC}

Determination of Slum Location at Semarang is based on the results of previous studies, Inventory and Identification of Slums in Semarang City 2010-2014, and its existence is administratively legal and does not conflict with the spatial regulation of Semarang City. Referring to the results of the inventory, in Banyumanik District there is 27.5 ha of slum area and consists of 321 housing units [11].

TABLE 3. Number of Slum Houses at Banyumanik District

\begin{tabular}{lllcc}
\hline No & Subdistrict & \multicolumn{1}{c}{ Location } & Wide (ha) & Number of houses \\
\hline 1. & Ngesrep & RT 05/RW II & $0,59 \mathrm{Ha}$ & 22 units \\
\hline 2. & Padangsari & RT 03/RW III & $0,49 \mathrm{Ha}$ & 30 units \\
\hline 3. & Jabungan & RT 01/RW V & $11,68 \mathrm{Ha}$ & 41 units \\
\hline \multicolumn{5}{c}{ RT 01/RW IV } \\
\hline 4. & Tinjomoyo & RT 4/RW II & 40 units \\
\hline R. & Srondol Kulon & RT 06/RW I & 52 units \\
\hline 6. & Gedawang & RT 05/RW II & $3,57 \mathrm{Ha}$ & 35 units \\
\hline
\end{tabular}

Source: Decree of Mayor of Semarang No. 050/801/2014, observation, 2016

\section{Physical condition}

\section{Land area and Building Area}

The average of slum land area in Banyumanik district varies from $50 \mathrm{~m}^{2}$ to $150 \mathrm{~m}^{2}$. Whereas, the comparison of the building's floor area to the land area was quite varied, ranging from $50 \%$ to $80 \%$, even though some reaches $100 \%$. 


\section{Distance between buildings}

The average of distance between buildings is 2-3 m (RT 01/V of Jabungan, RT 05/II of Ngesrep, and RT 03/III of Padangsari). In addition, most of them do not have distance at all (RT 01/IV of Jabungan, RT 04/II of Jabungan, RT 05/I of Tinjomoyo, RT 06/I of Srondol Kulon, and RT 05/II of Gedawang).

TABLE 4. Land Area and Building Area of Slum in Banyumanik District

\begin{tabular}{ccc}
\hline Location & Average of land area $\left(\mathrm{m}^{2}\right)$ & Average of building area $\left(\mathrm{m}^{2}\right)$ \\
\hline RT 05/II of Ngesrep & 100 & 60 \\
\hline RT 03/III of Padangsari & 50 & 50 \\
\hline RT 01/V of Jabungan & 150 & 70 \\
\hline RT 01/IV of Jabungan & 120 & $50-100$ \\
\hline RT 04/II of Jabungan & 120 & 80 \\
\hline RT 05/I of Tinjomoyo & 120 & 60 \\
\hline $\begin{array}{l}\text { RT 06/I of Srondol } \\
\text { Kulon }\end{array}$ & 60 & 60 \\
\hline RT 05/II of Gedawang & 60 & 100
\end{tabular}

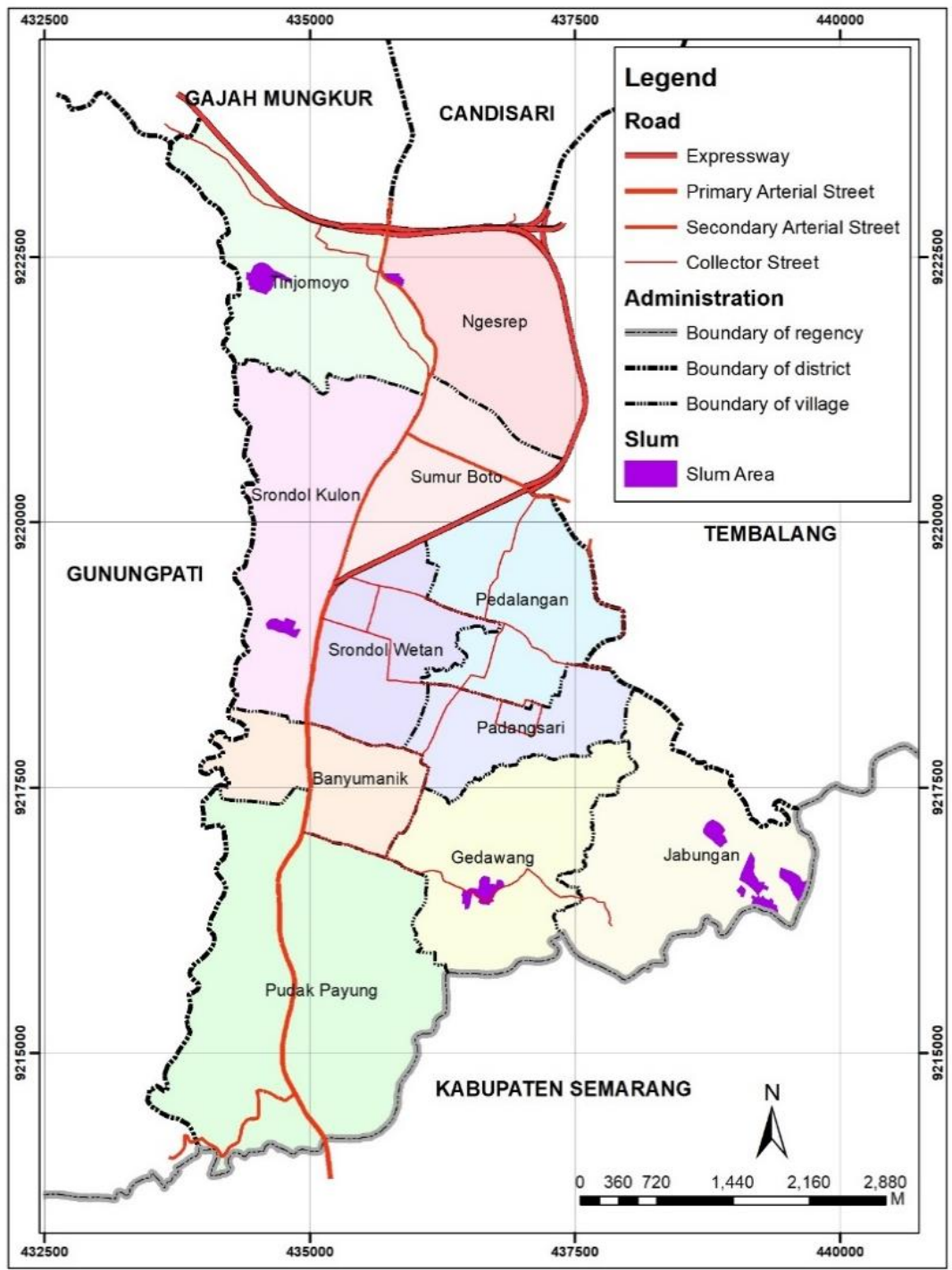

FIGURE 1 Map of Slum Location in Banyumanik District [12] 


\section{Condition of The Floor}

Overview of condition of the floor is based on the identification on each room in the house. In general, most of the houses are cemented/stucco, some are tiled and ceramic.

- Floors from cement/stucco are located in RT 5/RW II of Ngesrep, RT 3/RW V and RT 4/RW II of Jabungan, and RT 5/RW I of Tinjomoyo. The proportion of houses with cement/stucco floors is about $50 \%$ of slum dwellings located in Banyumanik District.

- Floors from tiles (around 31.25\%) are located in RT 3/RW III of Padangsari, RT 6/RW I of Srondol Kulon and RT 5/RW II of Gedawang.

- Floors from ceramics (around 18.75\%) are located in RT 1/ RW IV of Jabungan and RT 5/RW of II Gedawang.

The condition of The Wall

Based on the results of slum buildings identification, the walls of house building are made from the plastered bricks, unplastered brick walls, bricks-wood/bamboo, and wood/bamboo.

- Walls with plaster brick (12.5\%) are located in RT 5/RW II of Gedawang.

- Unplastered brick walls (12.5\%) are located in RT 3/RW III of Padangsari.

- Walls with Brick-wood/bamboo (50\%) are dominate in Banyumanik's slum area. Houses with these conditions are in RT 5/RW II of Ngesrep, RT 3/RW V and RT 4/RW II of Jabungan, and RT 5/RW I of Tinjomoyo.

- Walls which made from wood/bamboo (25\%) located in RT 1/RW IV of Jabungan and RT 6/RW I of Srondol Kulon.

\section{Socio-economic condition}

\section{Income and education level}

Following the findings of the study, it is known that there is a tendency of the income level of the population in slum location is low (earnings per households less than the minimum wage of Semarang city /less than Rp 1.500.000,00). The number of households with income less than Rp 1.500.000, 00 is about $60 \%$ of all existing households. The lack of income is caused by the low level of education. Therefore, the people cannot work in the formal sector because most of them are farmers, traders, factory workers and rough workers. Based on the level of education, about $66 \%$ population only graduated from junior high school, $22 \%$ graduated from high school, $6 \%$ graduated from elementary school, and the rest are graduated from diploma program/university.

\section{Nutritional status of children under five and morbidity rate}

The nutritional status determined by the percentage of children under five year old with malnutrition is less than $10 \%$, except in RT $01 / \mathrm{IV}$ of Jabungan (31-50\%). This is caused by the economic conditions and an understanding of the importance fulfillment of the nutrition for children under five years old.

The morbidity rate is the percentage of people affected by certain diseases per year [13]. The average of morbidity rate is less than $5 \%$, except RT $02 / \mathrm{V}$ of Ngesrep with dengue fever and diarrhea (6-10\%), and RT $01 / \mathrm{V}$ of Tinjomoyo with diarrhea rate ranges from 6 to $10 \%$ [14].

\section{Infrastructure Condition}

\section{Clean Water Service}

In general, all households are served by clean water infrastructure either from PDAM or shallow well water, with decent condition. However, some water source is not suitable to be consumed, i.e. in the slum that is located in RT 1/RW V of Jabungan. In general, the number of households which are not served by clean water is on average $10 \%-30 \%$. The number of households which have not received clean water service is $<10 \%$ and they are located in RT 5/RW II of Ngesrep, RT 3/RW III Padangsari, RT 1/RW V of Jabungan, and RT 5/RW II of Gedawang. While, $50 \%$ of the area located in RT 1/ RW IV of Jabungan does not have the clean water service.

\section{Sanitation}

Almost all households already have private restrooms. There are still some public toilets in some areas. Four units at RT 3/RW V of Jabungan are built from the community's funding. Two units at RT 1/RW IV of 
Jabungan are built by the private company. Two units at RT 4/RW II of Jabungan are built from a governmental grant from and four units at RT 5/RW I of Tinjomoyo are also built from the governmental aid. While the public toilets at RT 3/RW V of Jabungan, and RT 5/RW I of Tinjomoyo are managed by community groups.

The number of households who do not use restrooms at the community at RT 01/RW V of Jabungan, RT 05/RW II of Ngesrep, RT 03/RW III of Padangsari, RT 05/RW I of Tinjomoyo, RT 06/RW I of Srondol Kulon, and RT 05/RW II of Gedawang is less than $10 \%$ of the population. While, RT 4/RW II of Jabungan is about 31$50 \%$, and the highest is at RT 1/RW 4 Jabungan about $61-70 \%$ of the population.

\section{Solid Waste}

There is one garbage dump in RT 5/RW II Ngesrep by government aid. For other areas, the garbage disposal is still using a vacant land. Concerning the number of households who do not have the solid waste service, RT 5/RW II of Ngesrep is $<10 \%$, RT 1/RW IV and RT 4/RW II of Jabungan are about 11-30\%, and the other areas are over $70 \%$.

\section{Drainage Channel}

In some slums area in Banyumanik District do not have proper drainage systems because there are not even drainage networks, such as in RT 3/RW III of Padangsari, RT 1/RW V of Jabungan, RT 6/RW I of Srondol Kulon, and RT 5/RW II of Gedawang. The existing drainage channel has $15-50 \mathrm{~cm}$ of wide. The condition of drainage in some areas is not clogged, but because of small dimensions and bad condition, when it rains some channels cannot accommodate rainwater. This causes a flood/puddle moment when rain falls.

The existence of the drainage network is found in the Ngesrep region with dimensions: width of $50 \mathrm{~cm}, 20$ $\mathrm{cm}$ depth, by bricks. In Padangsari, the existing drainage channel has a diameter of $20 \mathrm{~cm}$, a depth of $10 \mathrm{~cm}$, with concrete pavement, and the drainage length that is clogged with $<10 \%$. In RT 4/RW II of Jabungan, the dimension of drainage channel is about $30 \mathrm{~cm}$ width, $20 \mathrm{~cm}$ depth, with soil material. In this location, the drainage length is not smooth between $11-25 \%$.

\section{Road Network}

The road network in Banyumanik District is dominated by asphalt and paving block, with the average width of the road is 1-4 meters. RT 04/I of Jabungan has the worst road condition with the percentage of road that damaged more than $70 \%$, and it also happened in RT 05/I of Jabungan which has the percentage of road that damaged $51-70 \%$.

TABLE 5. The condition of The Road in Banyumanik District

\begin{tabular}{cllll}
\hline No & \multicolumn{1}{c}{ Location } & $\begin{array}{c}\text { Wide of the } \\
\text { road }(\mathbf{m})\end{array}$ & Material & $\begin{array}{c}\text { Length of the damaged } \\
\text { road (\%) }\end{array}$ \\
\hline 1. & RT 05/II of Ngesrep & 2 & asphalt & $<10 \%$ \\
\hline 2. & RT 03/III of Padangsari & 1,5 & paving block & $11-30 \%$ \\
\hline 3. & RT 01/V of Jabungan & 1 & paving block & $51-70 \%$ \\
\hline 4. & RT 01/IV of Jabungan & 2 & paving block & $>70 \%$ \\
\hline 5. & RT 04/II of Jabungan & 4 & asphalt & $31-50 \%$ \\
\hline 6. & RT 05/I of Tinjomoyo & 1 & paving block & $11-30 \%$ \\
\hline 7. & RT 06/I of Srondol Kulon & 1 & concrete & $31-50 \%$ \\
\hline 8. & RT 05/II of Gedawang & 1 & paving block & $31-50 \%$ \\
\hline
\end{tabular}

\section{IMPACT OF INFRASTRUCTURE AVAILABILITY TO THE LEVEL OF SLUM AREA IN BANYUMANIK DISTRICT}

Referring to the Guidelines for Identification of Slum on Urban Buffer Areas [7], assessment of the availability of infrastructure that affects the level of slum area are: 


\section{Clean water conditions}

The scoring of clean water conditions is based on the number of households in residential areas that have obtained water flow from the water supply system, either from PDAM or shallow well water.

Based on the characteristics of the slum in Banyumanik District, only a slum area located in RT 01/IV of Jabungan is served by $30-60 \%$ clean water service (score: 20 ), and other regions have more than $60 \%$ (Score: 30 ). It is still far from the target to be achieved by the government, which seeks to realize $100 \%$ access to drinking water for all communities in 2019 through the "Program Kotaku (Kota Tanpa Kumuh)" [15], which would be achieved through the provision of available clean water.

\section{Sanitation Condition}

The scoring of sanitation conditions in slum areas takes into consideration the availability of private latrines and communal latrines that can be utilized by the local communities. Sanitation access is appropriate for the community as one of the targets to achieve at 2019, as contained in the National Medium Term Development Plan (RPJMN) 2015-2019 [16]. In Banyumanik District, the highest scoring (50) indicating that the area with $<30 \%$ private latrine availability is at RT 01/IV of Jabungan. This condition is still under the average of decent sanitation access in urban areas throughout Indonesia which is around 61\% in 2014 [17]. While in other regions the average $>60 \%$ of households use and have private latrines (score 20 ).

\section{Solid Waste Condition}

Solid waste service in each sub-district that has slum areas in Banyumanik is identified through the garbage disposal system by every household and the availability of garbage disposal facilities, both private and communal. Referring to the Regulation of the Minister of Public Works and People's Housing No. 02/PRT/M/2016 on Quality Improvement of Slum [18], waste management system affects the slum level in a region seen from the availability of infrastructure and facilities which meets the technical requirements, such as garbage bins with garbage sorting on every household, and the availability of garbage dump on environment scale. Based on the research criteria, the score of solid waste service has an average of 50, with the number of households served by the garbage $<50 \%$. However, in 3 slum areas found in RT 01/IV of Jabungan, RT 04/II of Jabungan, RT 05/II of Ngesrep, the service has reached 70\%, because at RT 05/II of Ngesrep supported by the availability of 1 unit of the garbage dump.

\section{Drainage System conditions}

In slum areas located in Banyumanik district, some of them do not have drainage network. The absence of drainage influences of slum level area. Because scoring is based on the results of drainage network conditions seen from the availability, dimensions, pavement, and clogged channel conditions. There are four areas which have clogged drainage more than 50\%, i.e., at RT 01/V of Jabungan, RT 01/IV of Jabungan, RT 06/I of Srondol Kulon, RT 05/II of Gedawang (score 50). Whereas at RT 05/II of Ngesrep, RT 03/III of Padangsari, RT 05/I of Tinjomoyo have good drainage condition, just about $<25 \%$ in bad condition.

\section{Road conditions}

The scoring of road conditions is based on the characteristics of roads in slum areas located in each subdistrict, observed from the pavement type and the extent of the damage. The highest level of damage road is found in RT 01/IV of Jabungan, which is about $70 \%$ of the existing road network in the area (score 50). While in other areas road network that suffered damage $<50 \%$ are in RT 05 / II of Ngesrep, RT 03/III of Padangsari, RT 04/II of Jabungan, RT 05/I of Tinjomoyo, RT 06/I of Srondol Kulon, and RT 05/II of Gedawang.

Referring to these criteria, the determination of slum level based on data processing of field study can be seen on table 6.

Based on the assessment, from the eight slum settlements scattered in Banyumanik District, the highest slum level is in RT 01/IV of Jabungan, with total score 200. This condition indicates that the availability of infrastructure in RT 01/IV of Jabungan is still limited when compared to the other slum locations. In addition, referring to the socio-economic conditions, the community has low-income levels, and the fulfillment of nutritional needs for children under five years old is also still below from the average of other slums. 
TABLE 6. Criteria and Assesment of Slum Area

\begin{tabular}{|c|c|c|c|c|c|c|c|c|c|}
\hline \multirow{3}{*}{ No } & \multirow{3}{*}{ Variable } & \multicolumn{8}{|c|}{ Sub-district } \\
\hline & & \multirow{2}{*}{$\begin{array}{c}\text { Ngesrep } \\
\text { RT05/II }\end{array}$} & \multirow{2}{*}{$\begin{array}{c}\begin{array}{c}\text { Padang- } \\
\text { sari }\end{array} \\
\text { RT03/III }\end{array}$} & \multicolumn{3}{|c|}{ Jabungan } & \multirow{2}{*}{$\begin{array}{c}\text { Tinjomoyo } \\
\text { RT05/I }\end{array}$} & \multirow{2}{*}{$\begin{array}{l}\begin{array}{c}\text { Srondol } \\
\text { Kulon }\end{array} \\
\text { RT 06/I }\end{array}$} & \multirow{2}{*}{$\begin{array}{c}\text { Gedawang } \\
\text { RT 05/II }\end{array}$} \\
\hline & & & & RT01/V & RT 01/IV & RT04/II & & & \\
\hline 1. & $\begin{array}{l}\text { Clean water } \\
\text { service (\% of the } \\
\text { number of } \\
\text { households which } \\
\text { are not served by } \\
\text { clean water } \\
\text { service) }\end{array}$ & 20 & 20 & 20 & 30 & 20 & 20 & 20 & 20 \\
\hline 2. & $\begin{array}{l}\text { Sanitation } \\
\text { Condition (\% of } \\
\text { the number of } \\
\text { households which } \\
\text { do not use private } \\
\text { restrooms) }\end{array}$ & 20 & 20 & 20 & 50 & 30 & 20 & 20 & 20 \\
\hline 3. & $\begin{array}{l}\text { Solid Waste } \\
\text { Condition (\% of } \\
\text { the number of } \\
\text { households are } \\
\text { not served well) }\end{array}$ & 20 & 50 & 50 & 20 & 20 & 50 & 50 & 50 \\
\hline 4. & $\begin{array}{l}\text { Drainage System } \\
\text { conditions (If it } \\
\text { has drainage, } \% \text { of } \\
\text { the drainage } \\
\text { length that } \\
\text { clogged) }\end{array}$ & 20 & 20 & 50 & 50 & 30 & 20 & 50 & 50 \\
\hline 5. & $\begin{array}{l}\text { Road condition } \\
\text { ( } \% \text { of the length } \\
\text { of damaged road) }\end{array}$ & 20 & 20 & 30 & 50 & 20 & 20 & 20 & 20 \\
\hline & Total score & 100 & 130 & 170 & 200 & 120 & 130 & 160 & 160 \\
\hline
\end{tabular}

\section{SUMMARY}

6 (six) slum areas in Banyumanik district have diverse infrastructure availability and services. PDAM's water supply service has not reached all slum areas, so some of them utilize shallow well water. However, in general, the service has been able to meet the needs of the community, except in the slum areas found in RT 1/RW IV Jabungan. In that sub-district, approximately 50\% of the people has clean water service . Sanitation infrastructure, in general, has reached the entire region. Most of the people already have private restrooms, and in some areas have communal latrines from government aid and the private company. Whereas the garbage disposal system, there's supported by the presence of 1 (one) garbage dump at RT 5 / RW II of Ngesrep. The existence of drainage channels has not covered all of the existing territories. While in some areas that some areas already have drainage network, dimensions and conditions have not supported to be used optimally. The road network is a crucial issue that needs to be considered, considering that from the condition have a high level of damage that is more than $50 \%$.

From that identification, slum areas located on RT 04/IV of Jabungan have the most limited availability of infrastructure. It makes that location have the highest level of slum compared with other slum areas in Banyumanik District. 


\section{ACKNOWLEDGMENTS}

Acknowledgments are addressed to the Department of Urban dan Regional Planning UNDIP that has funded this research.

\section{REFERENCES}

[1] S. Soetomo, Urbanisasi dan Morfologi: Proses Perkembangan Peradaban dan Wadah Ruang Fisiknya, Menuju Ruang Hidup yang Manusiawi. Yogyakarta: Graha Ilmu, 2009.

[2] I. Degert, P. Parikh, and R. Kabir, "Sustainability Assessment of a Slum Upgrading Intervention in Bangladesh," Cities J., pp. 63-73, 2016.

[3] O. O. Makinde, "Housing: Central City Slums, a case study of Ibadan.," J. Environ. Earth Sci., vol. 2, pp. 21-31, 2012.

[4] Bappeda Kota Semarang, "RPJMD Kota Semarang Tahun 2016-2021," 2016. [Online]. Available: https://bappeda.semarangkota.go.id/rpjmd.

[5] A. Ezeh et al., "The history, geography, and sociology of slums and the health problems of people who live in slums," Lancet, vol. 389, no. 10068, pp. 547-558, 2017.

[6] J. K. Brueckner, "Slums in developing countries: New evidence for Indonesia," J. Hous. Econ., vol. 22, no. 4, pp. 278-290, 2013

[7] Dinas Pekerjaan Umum, "Pedoman Identifikasi Kawasan Permukiman Kumuh daerah Penyangga Kota Metropolitan," $2009 . \quad$ [Online]. Available: http://ciptakarya.pu.go.id/dok/hukum/pedoman/panduan_identifikasi_kawasan_permukiman_kumuh.pdf

[8] Pemerintah Kota Semarang, "Program Penanganan Permukiman Kumuh Kota Semarang," 2014. [Online]. $\quad$ Available: http://www.p2kp.org/warta/files/Program_Penanganan_Kumuh_Kota_Semarang.pdf.

[9] J. T. Jayadinata, Tata Guna Tanah Dalam Perencanaan Pedesaan Perkotaan dan Wilayah. Bandung: Penerbit ITB, 1992.

[10] R. J. Lilford et al., "Improving the health and welfare of people who live in slums," Lancet, vol. 389, pp. 559-570, 2017.

[11] SK Walikota Semarang No 050/801/2014, Penetapan Lokasi Lingkungan Perumahan dan Permukiman Kumuh Kota Semarang. Semarang, 2014.

[12] Bappeda Kota Semarang, "Spatial Plan of Semarang City 2011-2031," 2010.

[13] N. M. Butala, M. J. VanRooyen, and R. B. Patel, "Improved Health Outcomes in Urban Slums Through Infrastructure Upgrading," Soc. Sci. Med., no. 71, pp. 935-940, 2010.

[14] BPS, "Profil Kecamatan Banyumanik," 2016.

[15] Dinas Pekerjaan Umum, "Program Kotaku," 2017. [Online]. Available: kotaku.pu.go.id.

[16] Bappenas, “Rencana Pembangunan Jangka Menengah Nasional 2015-2019,” 2017. [Online]. Available: https://www.bappenas.go.id/id/data-dan-informasi-utama/dokumen-perencanaan-danpelaksanaan/dokumen-rencana-pembangunan-nasional/rpjp-2005-2025/rpjmn-2015-2019/.

[17] BPS, "Persentase Rumah Tangga menurut Provinsi dan Memiliki Akses terhadap Sanitasi Layak," 2016. [Online]. Available: https://www.bps.go.id/statictable/2016/.

[18] Dinas Pekerjaan Umum, "PERATURAN MENTERI PEKERJAAN UMUM DAN PERUMAHAN RAKYAT REPUBLIK INDONESIA NOMOR 02/PRT/M/2016 TENTANG PENINGKATAN KUALITAS TERHADAP PERUMAHAN KUMUH DAN PERMUKIMAN KUMUH,” 2016. [Online]. Available: http://birohukum.pu.go.id/uploads/DPU/2016/PermenPUPR02-2016.pdf. 